\title{
Contribution of Macroprudensial Policy of Central Bank On Microprudensial Islamic Banking
}

\author{
Riduwan and Rofiul Wahyudi \\ Abmad Dablan University Yogyakarta \\ riduwan@pbs.uad.ac.id, rofiul.wahyudi@pbs.uad.ac.id
}

\begin{abstract}
The purpose of this research will be to answer the contribution of the macroprudential policy of Central Bank to the microprudential of islamic banking during the period of January 2008 - February 2016. The method used by quantitative analysis with panel data regression to be able to describe macroprudential policy contribution to FDR of islamic banking in Indonesia. Macroprudential policy instruments use Loan-to-Value Ratio (LTR), Statutory Reserves (GWM) based on Loan-to-Funding Ratio (LFR) and Countercyclical Capital Buffer (CCB). The islamic bankingmicroprudential instrument used is Financing to Deposit Ratio (FDR). The result shows that macroprudential policy contribution through LTV instrument to FDR has negative and significant influence. Statutory Reserves based on LFR on FDR have a positive and significant influence and CCB on FDR of Indonesia's islamic banking shows negative and significant influence.
\end{abstract}

Keywords: Financing, Macroprudential Central Bank, Microprudential islamic banking

\section{Abstrak}

Tujuan penelitian ini akan menjawab kontribusi kebijakan makroprudensial Bank Sentral terhadap kinerja mikroprudensial perbankan syariab periode Januari 2008 - Februari 2016. Metode yang digunakan analisis kuantitatif dengan regresi data panel untuk dapat menggambarkan kontribusi kebijakan makroprudensial terhadap FDR perbankan syariab Indonesia. Instrumen kebijakan makroprudensial menggunakan Loan-to-Value Ratio (LTR), Giro Wajib Minimum (GWM) berdasarkan Loan-to-Funding Ratio (LFR) dan Countercyclical Capital Buffer (CCB). Instrumen mikroprudensial perbankan syariah yang digunakan yaitu Financing to Deposit Ratio (FDR). Hasilpenelitian menunjukkan kontribusi kebijakan makroprudensial melalui instrumen LTV terhadap FDR terdapat pengarub negatif dan signifikan. GWM berdasarkan LFR terbadap FDR terdapat pengarub positif dan signifikan dan CCB terhadap FDR perbankan syariah Indonesia menunjukan pengarub negatif dan signifikan.

Kata kunci: Pembiayaan, Makroprudensial Bank Sentral, Mikroprudensial Bank Syariah

Permalink/DOI:http://dx.doi.org/10.18326/infsl3.v11i2.291-308 


\section{Introduction}

Macroprudential policy is a countercyclical policy aimed at maintaining the resilience of the financial sector as a whole so as to be able to overcome systemic risks due to a collapse of institutions or financial markets that lead to crisis. While macroprudential is related to the level of health of individual financial institutions (banks and nonbank) in an effort to maintain the stability of the financial system Macroprudential policy is a countercyclical policy aimed at maintaining the overall financial sector resilience so as to be able to overcome systemic risk due to failure of institutions or financial markets that cause crisis. While macroprudential is related to the level of health of individual financial institutions (banks and nonbank) in an effort to maintain the stability of the financial system (Bank Indonesia, 2016), (Salter, 2014), (Grace, Hallissey, \& Woods, n.d.).

In Indonesia, the macroprudential approach has been implemented as part of the economic recovery due to the Asian financial crisis of $1997 / 1998$. The financial crisis is suspected to occur because of the absence of effective macroprudential policy in developed countries, namely the policy related to the dynamics in the financial sector that comes from the interaction between macroeconomic and micro economy (Bank Indonesia, 2016).

The financial system has a tendency to create procyclical, a state in which the economy grows faster when the phase of expansion and the economy worsens when the phase of contraction. When the economy is in a phase of expansion banks tend to increase lending in line with rising demand for credit and tend to ignore the risk, but on the contrary, when the economy is in the phase of contraction, banks tend to reduce lending in line with the demand for credit that fell. Against such procyclical behavior, a countercyclical policy is required which can break the economic growth rate too high during the expansion phase and accelerate low or even negative economic growth during the contraction phase (Matheus \& Yoel, 2016). 
The condition of Islamic banking Indonesia shows a positive development with the high growth of Assets, Financing Distributed (PYD), and Third Party Funds (DPK). All performance indicators show improvement. islamic banking indicators are shown by 13 Sharia Commercial Banks (BUS), 21 Sharia Business Units (UUS), and 167 Sharia Rural Banks (BPRS). Procedural institutions also occur in islamic banking in Indonesia. Procyclical indicator occurs in the distribution of financing that is experiencing a slowdown and the growth of the last 5 years was pointed out as a result of the domestic and global economic slowdown response.

Financing to Deposit Ratio (FDR) of islamic banking shows fluctuation with declining trend. In 2012, a growth of $43.41 \%$, the condition of the year 2013 growth of $24.82 \%$ and $8.35 \%, 7.06 \%$ and $16.41 \%$ in 2014,2015 , and 2016 can be explained in the table as follows:

\section{Table 1}

Development of Financing Islamic Banking

\begin{tabular}{lccccc}
\hline \multicolumn{1}{c}{ Indikator } & $\mathbf{2 0 1 2}$ & $\mathbf{2 0 1 3}$ & $\mathbf{2 0 1 4}$ & $\mathbf{2 0 1 5}$ & $\mathbf{2 0 1 6}$ \\
\hline Financing (RpTriliun) & 151,06 & 188,55 & 204,31 & 218,72 & 254,7 \\
Growth (yoy) & $43,41 \%$ & $24,82 \%$ & $8,35 \%$ & $7,06 \%$ & $16,41 \%$ \\
\hline
\end{tabular}

Source: Statistics of islamic banking 2012-216 OJK

Responding to these conditions, the central bank issued a macroprudential policy to accelerate the growth of financing in order to maintain the stability of the financial system. Efforts to maintain financial system stability are not sufficient if only focused on macroprudential policy, but also microprudential (Lee, Gaspar, $\&$ Villaruel, 2017). A macroprudential policy has a wedge of close connection with the microprudential (Collin, Druant, \& Ferrari, 2014).

Macroprudential policy instruments in some countries. New Zealand uses macroprudential instruments core funding ratio (CFR); (ii) countercyclical capital buffer; (iii) sectoral capital requirements; and (iv) LTV ratios on loans to the residential 
property sector (Darbar \& Wu, 2015). The four instruments of a macroprudential policy of Bank Indonesia until the end of 2013 are among others Loan-to-Value Ratio (LTR), Reserve Requirements (GWM) based on Loan-to-Funding Ratio (LFR), Net Open Position (NOP) and Credit Base Rate Transparency (CBRT) (Ascarya, 2016). Its development in Indonesia has changed among others Loan-toValue Ratio (LTR), Giro Wajib Minimum (GWM) based on Loanto-Funding Ratio (LFR), and Countercyclical Capital Buffer (CCB).

The development of macroeconomics can put pressure on banks or banking systems such as Qudraty and Suriani (2017) analyzed the effectiveness of macroprudential policy stipulated by Bank Indonesia (BI) through Loan to Value (LTV), Loan to Deposit Ratio (LDR) instruments to lending of commercial banks in Aceh to PDRB Aceh as controlling variables indicate that macroprudential policy instruments set by $\mathrm{BI}$ affect the total lending of commercial banks in Aceh so that commercial banks in Aceh thus can reduce the risk of non-performing loans (Non Performing Loans).

Yoel (2016) examines how much and how the mechanisms of macro-prudential policy instruments CAR and GWM affect the credit cycle. The results showed that the CAR influenced the banking lending in a negative manner while the GWM influenced the banking credit lending positively both in the first model and the second model. In the second model, the researchers also found that CAR affects market ATMR positively. The authors conclude that the macro-prudential policies of CAR and GWM are quite effective in reducing the credit cycle.

The result of research by Purnawan and Nasir (2015) shows that aggregate GWM LDR policy is effective in raising bank credit. However, the impact of this policy varies across bank types. For foreign banks and this mix of policies is not effective. Event analysis shows that the movement of credit in state banks, foreign banks, and private banks tends to increase and is not procyclical. On the other hand, credit movements in regional development banks and mixed banks are very volatile and show the procyclical, both after the announcement and macroprudential policy is applied. 
Lim, C., et al. (2011) show that macroprudential policy instruments have an effect on effectively reducing the proliferation of credit. Hahm et al. (2011) show that macroprudential policy with LTV, LDR and GWM proxies is highly effective in credit cycles in South Korea. The Vihriala (1997) study linked credit provision to the state of the economy, that is, high credit expansion was done as the economy grew, financial liberation created a lending boom and moral hazard. Maria Fuertes and Espinola (2006) conducted the study using macroprudential and microprudential variables on the basis that financial institutions were weak when faced with macroeconomic shocks.

Based on the literature review, this study will answer how the contribution of previous macroprudential policy loan-to-Value Ratio (LTR), Statutory Reserves (GWM) based on Loan-to-Funding Ratio (LFR) and Countercyclical Capital Buffer (CCB) to increase microprudential performance with Financing to Deposit Ratio (FDR) of islamic banking.

The study is aimed to investigate contribution of previous macroprudential policy loan-to-Value Ratio (LTR) to increase microprudential performance with Financing to Deposit Ratio (FDR) of islamic banking. Investigate contribution of previous macroprudential policy Statutory Reserves (GWM) based on Loanto-Funding Ratio (LFR) to increase microprudential performance with Financing to Deposit Ratio (FDR) of islamic banking. To investigate contribution of previous macroprudential policy Countercyclical Capital Buffer (CCB) to increase microprudential performance with Financing to Deposit Ratio (FDR) of islamic banking.

\section{Theoretical Review}

\section{Macroprudential Policies}

Maintaining financial system stability can be achieved through two approaches, macroprudential policy and microprudential policy (Bank Indonesia 2007). Macroprudential policy is a countercyclical policy aimed at maintaining the resilience of the financial sector as a whole so as to be able to overcome systemic 
risks due to a collapse of institutions or financial markets that lead to crisis. While a microprudential policy is focused on the health of individual financial institutions (banks and non-banks) in order to maintain financial system stability, macroprudential policy is more oriented to the overall system (Bank Indonesia 2016).

Macroprudential policy is a policy aimed at improving financial system resilience and to mitigate systemic risk arising from inter-institutional linkages and the tendency of financial institutions to follow the economic cycle (procyclical) thereby increasing systemic risk (Working Group G-20, 2010). According to CGFS (2012), broadly macroprudential policy instruments in time dimension are divided into three, namely capital-based instruments, liquidity-based instruments, and asset-based instruments.

The following are some of the macroprudential policy instruments implemented in Indonesia, which are managed by Bank Indonesia such as Loan-to-Value Ratio (LTR), Statutory Reserves (GWM) based on Loan-to-Funding Ratio (LFR) and Countercyclical Capital Buffer (CCB ) (Bank Indonesia, 2016). According to Bank Indonesia (2016), the formulation of LTV policy on KPR and DP on KKB was motivated by the high growth of property and motor vehicle credit at that time, potentially creating systemic risk due to excessive risk-taking behavior. The minimum limitation policy on LTV for KPR and DP for KKB has been adjusted twice in 2013 and 2015. The last change made is easing (expansion) with the aim to maintain the momentum of economic growth through the improvement of the intermediation function, so that banks can disburse more lots of credit. The minimum value of LTV and DP currently applicable is stipulated in Bank Indonesia Regulation Number. 17/10/PBI/2015 dated June 18, 2015, on Loan-to-Value Ratios or Financing-to-Value Ratios for Credit or Property Financing and Advances for Credit or Motor Vehicle Financing.

Furthermore, according to Bank Indonesia (2016), the LFR GWM instrument shall be the minimum deposit in Rupiah that must be maintained by the bank in the form of a demand deposit account balance with Bank Indonesia, at a certain percentage of third-party funds calculated on the difference between LFR owned by bank with target LFR. this policy is expected to encourage the creation 
of a balanced and quality intermediary function while maintaining bank liquidity conditions. The policy on the LFR Statutory Reserves is set forth in Bank Indonesia Regulation no. 17/11/PBI/2015 dated June 26, 2015, concerning Amendment to PBI number. 15/15/ PBI/2015 concerning Statutory Reserves of Commercial Banks in Rupiah and Foreign Currency for Conventional Commercial Banks. Countercyclical Capital Buffer (CCB) is an additional capital that serves as a buffer (buffer) to anticipate losses in case of excessive credit growth and/or bank financing, thus potentially disrupting the stability of the financial system. As mentioned earlier, this policy is one of the policies formulated in the international mandate, by looking at the phenomenon of a proliferation of credit growth trends, namely rapid growth in the rapidly booming and declining growth even in times of economic downturn (bust), thus potentially leading to an increase in systemic risk in boom economic conditions. Implementation of CCB policy in Indonesia is regulated in Bank Indonesia Regulation no. 17/22 /PBI/2015 dated December 23, 2015, on the Obligation of Countercyclical Buffer Establishment.

\section{Microprudential Policies}

The microprudential policy focused on the health of individual financial institutions is more emphasized on the crosssectional dimension, ie how the risks are amplified within 1 (one) specific period. In fact, the behavior of financial institutions from time to time also need to be considered. The health of a financial institution assessed at a given time is incapable of illustrating the evolution of risk existing in the institution. Because in reality, the movements of financial institutions tend to be in line with the ups and downs of the economy that characterizes the risktaking behavior (procyclicality). When economic conditions are in good shape, financial institutions will expand and increase risk-taking behavior. Meanwhile, when economic conditions are bad, financial institutions tend to withstand expansion, reduce risks including restraining lending. Macroprudential policy characteristics that include time series and cross sections can complement microprudential policy in reducing risk amplification (Bank Indonesia, 2016). Microprudential functions related to the 
health, performance, and sustainability of individual business of the bank are transferred to the Financial Services Authority from 31 December 2013, while Bank Indonesia is mandated to remain in the macroprudential function.

Macroprudential policy is a system-oriented policy, aiming to see the financial system as a whole through a top-down approach. With a top-down approach, the policy will be based on a comprehensive analysis of macroeconomic conditions and their impact on all risks in the financial system, including the correlation between systemic risk, market dynamics, and policy options. This policy characteristic addresses the need for an aggregate approach to creating financial system stability. Thus, a macroprudential policy with a top-down approach will complement the microprudential policy focused on a bottom-up approach through a more in-depth analysis of the risk of individual financial institutions (idiosyncratic risk) (Bank Indonesia 2016).

Bank Indonesia (2016) The interaction between macroprudential policy and microprudential policy is easier to observe, since macroprudential policy is essentially implemented using microprudential instruments, but is applied with a different purpose than microprudential purposes. In macroprudential policy, sometimes the health of some financial institutions has to be sacrificed if it can save the financial system as a whole. For example, when credit distribution is excessive, macroprudential policy will formulate additional minimum requirements for bank capital, thus encouraging banks to reduce the profit-taking (Countercyclical Capital Buffer / CCB). This buffer capital is intended to be used by banks to absorb losses when economic conditions decline where credit performance tends to decline. For banks, this will increase their funding costs so as to reduce their profits. Some banks may find it difficult to meet these minimum capital increases so that their health levels are declining, but this will protect the entire banking system that needs to be on the lookout for reversing economic conditions. Therefore, it is also natural that macroprudential policy tends to focus on financial institutions that have systemic impacts (eg systemic bank or systemically important banks), by implementing strict rules to maintain the sustainability of these financial institutions, so as to not pose a systemic risk. 


\section{Conceptual framework}

This framework is a model of research concepts explaining the relationship between theory, concept and reinforced by previous research. Empirically, several studies on the implementation of macroprudential policy towards microprudential Islamic banking. According to Jeong, (2009) using a sample of bank-level data combined with relevant macro data to identify, using quarterly data from twenty-five Korean commercial banks over the period 1993-2008 includes all commercial banks in Korea. Suggests the estimation results by OLS when using real GDP growth rates as a proxy of the business cycle. The coefficient on the growth rate of GDP for 1993-1999 was 0.52 and for 1999-2008 was 1.4 both were significant at the 99\% level. This result shows after the financial crisis, the procyclical of the bank's behavior in corporate credit is positively significant. Tovar, Garcia-Escribano and Martin (2012) are seeking macroprudential instruments of reserve requirement on credit growth in Latin America covering five countries: Brazil, Chile, Colombia, Mexico, and Peru. The result of research indicates that macroprudential instrument that is reserve requirement has influence which is not too high and only short term for credit growth.Qudraty and Suriani (2017) analyze the effectiveness of macroprudential policy stipulated by Bank Indonesia (BI) through Loan to Value (LTV), Loan to Deposit Ratio (LDR) instruments to the lending of commercial banks in Aceh to PDRB Aceh as controlling variables. The result of the research shows that macroprudential policy instruments determined by BI affect the total credit distribution of commercial banks in Aceh so that commercial banks in Aceh can reduce non-performing loan (NPL) risk. However, Bank Indonesia should pay attention and evaluate the situation by looking at the macroprudential instruments which have the greatest impact on lending in Aceh Province.

Yoel (2016) examines how much and how the mechanisms of macro-prudential policy instruments CAR and GWM affect the credit cycle. The researcher constructed two models based on the theory of macroprudential policy transmission mechanisms on capital-based instruments and liquidity-based instruments. The results showed that the CAR influenced the banking lending 
in a negative manner while the GWM influenced the banking credit lending positively both in the first model and the second model. In the second model, the researchers also found that CAR affects market ATMR positively. The authors conclude that the macroprudential policies of CAR and GWM are quite effective in reducing the credit cycle.

Purnawan and Nasir (2015) show that aggregate GWM LDR policy is effective in raising bank credit. However, the impact of this policy varies across bank types. For foreign banks and mixed policies, this is not effective. Event analysis shows that the movement of credit in state banks, foreign banks, and private banks tends to increase and is not procyclical. On the other hand, credit movements in regional development banks and mixed banks are very volatile and show the procyclical, both after the announcement and macroprudential policy is applied. Findings Lim, C., et al. (2011) show that macroprudential policy instruments have an effect on effectively reducing the proliferation of credit.

Hahm et al. (2011) show that macroprudential policy with LTV, LDR and GWM proxies is highly effective in credit cycles in South Korea. The Vihriala (1997) study linked credit provision to the state of the economy, that is, high credit expansion was done as the economy grew, financial liberation created a lending boom and moral hazard. Maria Fuertes and Espinola (2006) conducted the study using macroprudential and microprudential variables on the basis that financial institutions were weak when faced with macroeconomic shocks.

Based on empirical theory and empirical studies, maintaining financial system stability is built on two approaches, macroprudential policy, and microprudential policy. because the financial sector is the main thing in the Indonesian economic system, the financial system is often used as a gateway to the sustainability of economic growth that is functioned through intermediation namely the distribution of financing. Therefore the frame of thought in the study can be explained in Figure 1. 


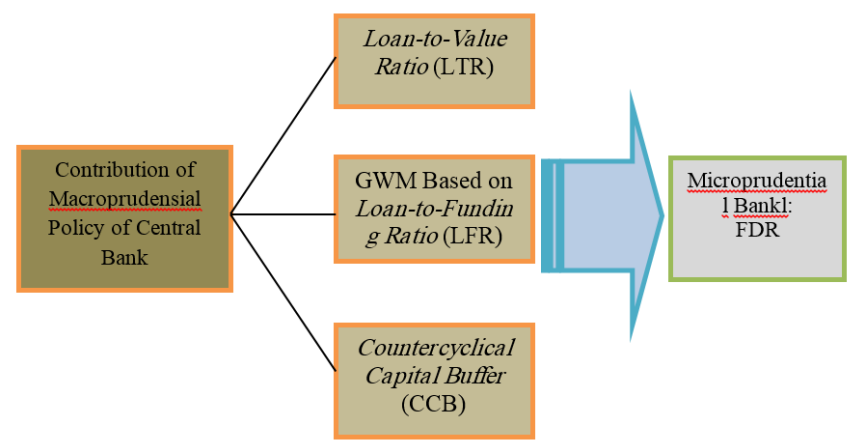

Figure 1. Framework

\section{Research Methods}

The method of this research is quantitative descriptive analysis method, that is the result of research which then processed and analyzed to be taken conclusion, it means research done is research which emphasizes its analysis on numerical data (number), using this research method will know significant relation between the variables studied, resulting in a conclusion that will clarify the picture of the object under study.

This study samples 12 of the population of all islamic bankings in Indonesia from the month of January 2008 to February 2016. One Syariah Commercial Bank is not a sample of Bank Aceh Syariah which is newly operated in 2016. Data obtained through the official website of Bank Indonesia ( www.bi.go.id). Microprudential data obtained by islamic banking Statistics (SPS) Financial Services Authority (OJK) (www.ojk.go.id).

Central Bank Macroprudential Policy Variables include; Loan-to-Value Ratio (LTR), Statutory Reserves (GWM) based on Loan-to-Funding Ratio (LFR) and Countercyclical Capital Buffer (CCB). Variable macroprudential islamic banking that is Financing to Deposit Ratio (FDR). Financing to Deposit Ratio (FDR) is a ratio used to measure the liquidity of a bank in repaying the withdrawal of funds deposited by relying on financing given as a source of liquidity, that is by dividing the amount of financing provided by the bank against Third Party Funds (DPK). Given the importance of 
the function and role of islamic banking in Indonesia, the islamic bankings need to improve their performance in order to create a islamic banking system that is healthy and efficient. FDR is the most appropriate indicator to measure the performance of a bank.

The analytical method used is panel data regression with fixed effect model with the help of statistical tool Eviews Ver. 9.0 to investigate the effect of the macroprudential policy of the Central Bank on the Microprudential Islamic banking of Indonesia.

\section{Result}

The result of the research by using panel data regression analysis concluded that the right regression model to explain the contribution of the macroprudential policy of Central Bank to the improvement of microprudential performance is fixed effect model.

Contribution Loan-to-Value Ratio (LTV) to Financing to Deposit Ratio

The result of the research on the contribution of macroprudential / Loan-to-Value Ratio (LTV) policy to FDR of Indonesia's islamic banking shows that there is a negative and significant influence on the policy of macroprudential / Loanto-Value Ratio (LTV) policy towards FDR of Indonesia's islamic banking. This means that when the government increases the minimum limit of LTV policy on mortgage and DP on KKB, then credit growth in property and motor vehicle sector will decrease. This condition is in line with the purpose of enacting the LTV policy that is to anticipate and minimize the growth of mortgage that is too high that can encourage the increase in property asset prices that do not reflect the actual price, thus increasing the credit risk for banks with large property loan disbursement. According to Bank Indonesia (2016), the formulation of LTV policy is motivated by the high growth of property and motor vehicle credit, thus potentially causing the formation of systemic risk due to excessive risk-taking behavior. 
The results of this study are in accordance with research conducted by Hahm et al (2009) on the effectiveness of using macroprudential policy instruments in South Korea, finding that the LTV policy as an effective macroprudential policy to reduce the credit cycle. Lim, et al (2011) in his study aimed at evaluating the effectiveness of the use of macroprudential instruments in reducing systemic risk, found that the LTV instrument effectively reduced the procyclical but its effectiveness depended heavily on shocks in the financial sector.

In the implementation of the LTV policy, the government implemented different LTV provisions in each period as a form of monitoring of the housing finance market. In the provisions of LTV I of 2012, there are restrictions on the rules that the maximum financing is $70 \%$, this is certainly causing a slowing growth in housing finance. Furthermore, in the amendment to the provisions of LTV II of 2013, the maximum financing difference is applied to the first, second and third house ownership. In the second provision of LTV also applied the prohibition of home financing pivot. Within 2 years after the implementation of the LTV II provisions, the government imposed relaxation on the LTV provisions in June 2015 by loosening the terms of housing financing to $80 \%$, while maintaining a distinction of ownership in the first, second and third homes for maximum financing. This is allegedly a government effort in encouraging better housing finance amid sluggish Indonesian economy.

Contribution Statutory Reserves (GWM) Based on Loan-to-Funding Ratio (LFR) to Financing to Deposit Ratio

The results of the research on the contribution of macroprudential / Giro (GWM) policy based on the Loan-to-Funding Ratio (LFR) to the FDR of Indonesian islamic banking show that there is a positive and significant influence on macroprudential policy / Statutory Reserves (GWM) based on Loan-to- Funding Ratio to FDR of Indonesia's islamic banking. This indicates that government policy in the form of GWM-LFR arrangement is able to encourage the creation of balanced and quality intermediary function while maintaining bank liquidity condition. According to 
Bank Indonesia (2015), the policy background of the GWM-LFR is implemented is to encourage economic growth through banking credit growth.

The results of research are in line with research conducted by Joel (2016) who examines how much and how the mechanisms of macro-prudential policy instruments CAR and GWM affect the credit cycle. The results of this study found that GWM affects the credit distribution of banks positively. Slightly different from those results, Tovar, Garcia-Escribano, and Martin (2012) explained that the application of reserve requirements as a countercyclical policy has a not too high and short-term effect on credit growth.

According to Joel (2016), the positive effect of GWM on credit given by banks is different from the theory of macroprudential policy mechanisms on liquidity-based instruments as well as with some other studies saying that the increase in the reserve requirement makes the amount of credit disbursed by banks is reduced as a result of banks having to set aside more reserves to meet the regulation. Yoel (2016) explains that this is because Bank Indonesia has established an LDR-based GWM regulation in 2008 where banks with LDR (Loan to Deposit Ratio) below the lower limit of LDRs will be charged additional GWM. This is aimed at encouraging banking intermediation function while maintaining prudent principles.

Contribution Countercyclical Capital Buffer (CCB) to Financing to Deposit Ratio

The results of the research on the contribution of macro prudential/countercyclical capital buffer (CCB) to the FDR of Indonesian islamic banking show that there is a negative and significant influence of the policy of Counter-Cyclical Capital Buffer (CCB) to the FDR of Indonesian islamic banking. This means that when the government increases the number of bank capital buffers, then the condition will lower the level of credit/ financing in Indonesia. The results of this study are in line with research conducted by Pramono, et al (2015) that changes in capital regulations, such as CCB have a negative and significant relationship in affecting credit growth. Therefore, this review 
recommends $\mathrm{CCB}$ to be implemented in Indonesia because CCB can effectively withstand the rate of credit growth in Indonesia.

According to Gambacorta and Mistrulli (2003), in the economic literature, there are two transmissions of how changes in bank capital can affect credit, namely lending channel and capital channel. Both transmissions are based on an irrelevant capital structure of a company/bank using the perfect market assumption on Modigliani-Miller theorem. In a perfect market, the bank will always be able to raise the level of funding (debt or equity) to fund the loan so that no regulatory requirements related to bank capital are needed. However, in reality, the market is imperfect and there is asymmetric information about the level of debt, equity, and banking assets. Lending channels depend on market imperfections on bank lending, while capital channels depend on market imperfections in banking equities (Gambacorta \& Mistrulli, 2003).

Bank lending channel can be explained when there is a tight monetary policy that can increase the cost of fund of the bank, especially for DPK, and also reduce interest margin as a result bank profitability will decrease. If in this condition the bank must increase its capital, the bank will react by increasing the credit terms. In the end, credit distribution will decrease due to increased cost for customers. For banks with strong capital and access to wider funds (not just DPK), such conditions are not a problem (Gambacorta \& Mistrulli, 2003). Meanwhile, bank capital buffer will decrease when there is an increase in minimum capital requirement.

Banks that do not have a high capital buffer and do not have wide access to other capital sources will make adjustments to the amount of credit disbursed. Conversely, banks that have buffer capital or have broader access to capital sources can adjust the amount of capital that must be met without affecting its loan portfolio. The second condition is if the market for bank equity is not perfect because the bank can not easily issue new equity, especially in the period of crisis 6 due to tax disadvantage and the problem of adverse selection and agency cost (Gambacorta \& Mistrulli, 2003). 


\section{Conclusions}

The research has succesfully answered the main propositions proposed earlier. First, The Contribution of Loan-to-Value Ratio (LTV) policy to FDR of Indonesian islamic banking shows that there is a negative and significant influence. This means that when the government increases the minimum limit of LTV policy on mortgage and DP on $\mathrm{KKB}$, then credit growth in property and motor vehicle sector will decrease.

Second, The contribution of Statutory Reserve (GWM) based on Loan-to-Funding Ratio (LFR) to FDR of Indonesia's islamic banking shows that there is a positive and significant influence. This indicates that government policy in the form of GWM-LFR arrangement is able to encourage the creation of balanced and quality intermediary function while maintaining bank liquidity condition.

Third, The contribution of macroprudential policy / Countercyclical Capital Buffer (CCB) to FDR of Indonesia's islamic banking shows that there is a negative and significant influence. This means that when the government increases the number of bank capital buffers, then the condition will lower the level of credit/financing in Indonesia.

Based on study results, macroprudential policy implementation consisting of Loan-to-Value Ratio (LTV) policy, Minimum Reserve Requirements (GWM) policy based on Loanto-Funding Ratio (LFR), and Countercyclical Capital Buffer (CCB) policy pressing the rate of credit growth. Therefore, the policy can be recommended as a macroprudential policy instrument to help address the possibility of systemic risks arising from excessive credit growth during the phase of economic expansion.

The results of this study are expected to be a reference for further investigators in discussing the contribution of macroprudential policy in suppressing the rate of credit growth. For further research, it is advisable to examine the contribution of macroprudential central bank policy in suppressing the rate of credit growth by adding other macroprudential policies such as Net Open Position (NOP) and Credit Base Rate Transparency (CBRT). 


\section{Reference}

Agung, Juda. 2010. Mengintegrasikan Kebijakan Moneter dan Makroprudensial: Menuju Paradigma Baru Kebijakan Moneter Indonesia Pasca Krisis Global. Working Paper, No, 07, Bank Indonesia.

Bank Indonesia. 2016. Mengupas Kebijakan Makroprudensial. Departemen Kebijakan Makroprudensial.

Committee on the Global Financial System. (2012). Operationalising the selection and application of macroprudential instruments. BIS CGFS Papers, 48.

Calomiris, Charles W., et al. (2004). A Taxonomy of Financial Crisis Resolution Mechanism: Cross Country Experience. World Bank Policy Research Working.

Gambacorta, L., \& Mistrulli, P.M., (2003) "Bank Capital and Lending Behaviour : Empirical Evidence for Italy “. Banca d'Italia, Research Deparment.

Hahm, J. H., Frederic S. Mishkin, Hyun Song Shin and Kwanho Shin. 2011. Macroprudential Policies in Open Emerging Economies. Asia Economic Policy Conference. Hal 63-114.

Islamic Development Bank.2010. Report of the Task Force on Islamic Finance and Global Financial Stability, April, 2010.

Jeong HK (2009) "The Procyclicality of Bank lending and its funding structure: The case of Korea". Paper prepared for 2009 BOK International conference on the credit crisis: theoretical perspective and policy implication.

Kurnia, dkk. 2015. Islamic Finance Outlook 2015. Karim Consulting Indonesia

Lim, C., et al. 2011. Macroprudential Policy: What Instruments and How to Use Them? Lessons from Country Experiences. IMF Working Paper

Lim, C., F. Columba, A. Costa, P. Kongsamu, A. Otani, M. Saiyid, T. Wezel, and X.Wu. 2011. IMF Working Paper. Monetary and Capital Markets Department. Macroprudensial Policy: What IInstrument and How to Use Them? Lessons From Country Experiences. October 2011. Hal 1-84. 
Meutia qudraty dan suriani. Efektifitas Kebijakan Makroprudensial Perbankan dan Penyaluran Kredit di Aceh. Jurnal Perspektif Ekonomi Darussalam, Volume 2 Nomor 1, Maret 2016

Miskhin, Frederic S. (1999). Lessons from the Asian Crisis. Journal of Interational Money and Finance, Vol. 18, page.709-723.

Muhammad Edhie Purnawan dan M. Abd. Nasir, The Role of Macroprudential Policy to Manage Exchange Rate Volatility, Excess Banking Liquidity and Credits. Buletin Ekonomi Moneter dan Perbankan, Volume 18, Nomor 1, Juli 2015

Pramono, B., Januar H., Justina A., Maulana H M., Muhammad S A., 2015. Dampak Kebijakan Countercyclical Capital Buffer Terhadap Pertumbuhan Kredit Di Indonesia. Working Paper Bank Indonesia.

Vihriala, Vesa. 1997. Banks and the Finish Credit Cycle, 1986-1995. Suomen Pankki, Bank Finland. Bank of Finland Studies E: 7, 1997, Helsinki.

Working Group G-30. 2010. Enhancing Financial Stability and Resilience: Macroprudential Policy, Tools, and Systems for the Future. Working Paper G-30 